\title{
Analysis of Open Innovation Practices in Malaysian SMEs
}

\author{
Ashkan Rangamiztousi \\ Faculty of Management, Universiti Teknologi Malaysia (UTM) \\ 81310 UTM Skudai, Johor, Malaysia
}

Tel: 60-10-714-3387_E-mail: rashkan2@live.utm.my

Assoc. Prof. Dr. Kamariah Bt Ismail (Corresponding author)

Faculty of Management, Universiti Teknologi Malaysia (UTM)

81310 UTM Skudai, Johor, Malaysia

Tel: 60-07-556-6911Ｅ-mail: m-maria@utm.my

\author{
Received: Oct. 26, $2015 \quad$ Accepted: Nov. 19, $2015 \quad$ Published: January 1, 2016 \\ doi:10.5296/jmr.v8i1.8490 \\ URL: http://dx.doi.org/10.5296/jmr.v8i1.8490
}

\begin{abstract}
Open Innovation is a phenomenon that has become increasingly important due to found shorter innovation cycles, industrial R\&D escalating costs as well as in the dearth of resources. Researchers have suggested various kinds of practices and ways to categorized them. However, most of prior studies only used some of the practices to measured open innovation, but the measurements were very generic as some practices are broadly defined, and the list of open innovation activities not included new activities and completed list of practices. Hence, it is crucial to identify a new list of open innovation practices and study on similar practices in developing countries to help their companies understand open innovation and its practices as well. This study reviewing prior studies on open innovation adoption published between 2003 and March 2014 and identified 36 different practices. Therefore, we created a new list of open innovation practices that cover most of strategies and practices mentioned in prior studies. This study used quantitative methodology, 400 high rank executives manager of Malaysia SMEs participated and completed the survey and further analyzed using the appropriate statistical procedures. The results indicated that Malaysian SMEs use three core processes of open innovation including coupled, outside-in, and inside-out practices in their open innovation processes, respectively.
\end{abstract}

Keywords: Open innovation, Practices, Strategies, SMEs, Malaysia 


\section{Introduction}

Technological change and innovation are amongst the most substantial sources of productivity growth, international competitiveness, and greater standard of living. In recent years, innovation management areas have become the centre of increasing attention due to intensive competition from rapidly emerging knowledge-based economies (Wynarczyk, Piperopoulos, \& McAdam, 2013). Specifically, research and policy attention have begun to highlight Small and Medium Enterprises (SMEs) as a key source, innovation and new product development driver, as well as supplier of new technologies. Moreover, SMEs play an important role in social and economic growth, due to a great number of industry, its Gross Domestic Product (GDP) contribution, and total employment. Therefore, innovative SMEs comprise a substantial part of a dynamic process of regional and national economic development and international competiveness. Amongst such innovative firms, only few have the desire, capacity, and opportunity to actively and successfully pursue growth, expansion and diversification beyond their local boundaries. SMEs are hindered by internal and external structural impediments such as smallness, managerial capacity, skills, awareness of, and access to external knowledge and financing (Wynarczyk et al., 2013).

According to (Rosenbusch, Brinckmann, \& Bausch, 2011), in order to have resource-scarce SEMs, it is necessary to be oriented into innovation. Innovation helps to bind and attract different types of resources, for example: recurring revenue by customers, qualified employees and financial resources from all of the investors that prefer larger and more established organizations. Therefore, the orientation towards innovation, such as open innovation (OI) strategies can be considered as influential response by SMEs for dealing with associated liabilities. Previous studies have shown that the advantages of SMEs orientation into innovation are more than tangible results, such as the production of new products, patents, production process, and services.

Open innovation has been defined as "a paradigm that assumes firms can, and should use external as well as internal ideas, and internal and external paths to market, as it looks for opportunities in advancing their technology" (Chesbrough, 2006a, p. 1). Moreover, Chesbrough, Vanhaverbeke, and West (2006, p. 1) have also defined open innovation as "the use of purposive inflows and outflows of knowledge to accelerate internal innovation, and to expand the markets for external use of innovation, respectively". Open innovation practices have also been observed in SME firms (Gronum \& Verreynne, 2011; Hu \& Chen, 2011; Idrissia, Amaraa, \& Landrya, 2012; Lee, Park, Yoon, \& Park, 2010; Suh \& Kim, 2012; Toedtling, Grillitsch, \& Hoeglinger, 2012; van de Vrande, de Jong, Vanhaverbeke, \& de Rochemont, 2009; Wynarczyk et al., 2013); whereby it is highlighted that openness assist to overcome smallness problems.

Nowadays, flexible strategies of innovation need for most enterprises to cope with environment changing. Therefore, to create a flexible and new innovation strategy firms should integrating different approaches, which take market demands and the enterprise's vision into account (Gassmann \& Enkel, 2004). In this regard, researchers have recommended several types of strategies and ways to categorized them (Gassmann \& Enkel, 
2004; Herzog, 2011; van de Vrande et al., 2009). However, most of prior studies only used some of the practices to measured open innovation, but the measurements were very generic as some practices are broadly defined, and the list of open innovation activities not included new activities and completed list of practices. With this respect, van de Vrande et al. (2009) remarked that current innovation surveys, such as the Community Innovation Survey (CIS) and National Innovation Survey (NIS), mainly focus on R \& D and innovation investments of enterprises and external networking activities but disregard other open innovation practices.

In addition, most of these studies have been conducted in developed countries. Therefore, it is essential to identify a new list of practices of open innovation and study on similar practices in developing countries to help their companies understand open innovation and its practices as well. Moreover, classifying open innovation practices to understand approaches among several practices of open innovation will be great helpful tool for researchers and managers. Moreover, there are a lot of practices with almost the same definitions and various names and various kinds of categorizes that lead researchers to confront with difficulty to use in their studies. Consequently, reconsideration of definition and categorizing of those methods are essential. In this study, we review these definitions and categorize methods. Furthermore, through using exploratory factor analysis, we attempt to categorize open innovation practices so as to specify clear framework to open innovation.

\section{Literature Review}

Since 2003, open innovation model was popularised and suggested for innovation management and it was based on requirements of organisations to reveal their innovation processes and join externally and internally developed technologies to generate business values. The concept of open innovation has been introduced byChesbrough (2003a, 2003b) for the first time and then quickly became one of the main interests of practitioners and researchers, demonstrated by many dedicated conferences, special issue publications and also fast growing literatures (Elmquist, Fredberg, \& Ollila, 2009).

The open innovation paradigm (Chesbrough, 2003a, 2006a) stands in contrast to the vertical integrated innovation paradigm; where all knowledge is internalised and solely controlled by the firm (Chandler, 1977, 1990). The basic assumption of the open innovation concept is that the commercialisation of external sources of innovation and finding of external paths for commercialising internally sourced innovation is profitable for the firm (West \& Bogers, 2013). Gassmann and Enkel (2004) identified three core open innovation processes. First, the outside-in process of open innovation integrates a number of experts and collaborators into the innovation process and sources innovations from outside the company (e.g. inbound open innovation). Outside-in co-operation open innovation activities include the collaboration with external sources of innovation, e.g., customers and lead users (E. Von Hippel, 1988), online communities (Christensen et al., 2005) or any other external expert (West \& Bogers 2013). And also acquisition activities that include the internalisation of external intellectual property through licensing or purchasing the IPs (Gassmann \& Enkel, 2004; Laursen \& Salter, 2006; Schroll \& Mild, 2011). 
The second process is inside-out, open innovation encourages firms to utilise unused internal intellectual property (e.g. outbound open innovation) through selling patents, direct licensing or on intermediate markets (Arora, Fosfuri, \& Gambardella, 2001; Chesbrough, 2003a, 2007). This process makes profit by bringing ideas to market, selling Intellectual Property and multiplying technology via transferring ideas to the outside environment (Gassmann \& Enkel, 2004). And finally, the third process is coupled process; coupling the outside-in and inside-out processes by working in alliances with complementary partners in which give and take is crucial for success (Fey \& Birkinshaw, 2005; Gassmann \& Enkel, 2004; van de Vrande et al., 2009).

Various companies choose the similar mode of open innovation, or combined the all processes of open innovation to the same degree, it means some companies integrates different practices of open innovation from different processes and not only select one primary process (Gassmann \& Enkel, 2004). Based on Chesbrough et al. (2006) definition of Open Innovation as "the use of purposive inflows and outflows of knowledge to accelerate internal innovation, and to expand the markets for external use of innovation, respectively", hence, open innovation includes both inside-out and outside-in movements of ideas and technologies, so they are likewise referred to as "technology exploitation" and "technology acquisition" (U. Lichtenthaler, 2008). When firms completely open, they integrate both technology exploitation and technology exploration in order to generate extreme value from their technological capabilities or other competencies (Chesbrough \& Crowther, 2006; U. Lichtenthaler, 2008; van de Vrande et al., 2009).

Regarding to this categorization van de Vrande et al. (2009) identified three practices associated with exploitation of technology that includes licensing-out, employee involvement of non-R\&D workers in innovation initiatives, and venturing which is described as starting up new organizations based on internal knowledge (Arora et al., 2001; Chesbrough, 2003b, 2006b; Ulrich Lichtenthaler, 2007). And regarding to technology exploration they considered five activities that including outsourcing R\&D, external networking, customer involvement, external participation, and licensing-in of IP. Firms may outsource their R\&D activities to acquire knowledge from outside the boundaries of firms. For instance, technical service providers such as high-tech and engineering firms institutions have also become more essential in the process of innovation. Another important practice is external networking that is always related with open innovation (Chesbrough et al., 2006), which is comprises all activities to keep and acquire connections with external sources of knowledge such as organizations and individuals. It likewise includes both informal networking activities and formal collaborative projects and more general. Regarding to costumer and lead users involvement Von Hipple $(1988,2005)$ stated that they are not just passive innovations adopters; nevertheless they may rather develop their own innovations that producers can copy and replicate. External participations assist the retrieval of innovations that were initially abandoned or that did not seem promising. Firms may invest in start-ups and other businesses to keep an eye on potential opportunities (Chesbrough, 2006a). Such equity investments provide opportunities to further increase external collaboration in case their technologies prove to be valuable (Van De Vrande, Lemmens, \& Vanhaverbeke, 2006). Finally, firms can 
acquire IP externally; including the licensing of trademarks patents or, copyrights to benefit from external innovation opportunities (Chesbrough, 2006a). Another study categorized open innovation through systematic content analysis of all papers on the topic published in Thomson's ISI Web of Knowledge (ISI) by Dahlander and Gann (2010) that their review indicated two outbound processes: revealing and selling, and two inbound processes, sourcing and acquiring. Outbound process is related with external exploitation of internal knowledge, while inbound process refers to internal use of external knowledge.

Bianchi, Cavaliere, Chiaroni, Frattini, and Chiesa (2011) also identified three outbound and inbound practices that include non-equity alliances, licensing agreements (in and out), and technical and scientific services (supply and purchase). General practices for inbound open innovation comprise R\&D contracts and funding of research, licensing-in, acquisitions, minority equity investments, joint ventures, purchase of scientific and technical services and non-equity alliances. Regarding to outbound practices of open innovation are comprise spinning out of new ventures, licensing-out, joint venture for technology commercialization, sale of innovation projects, supply of scientific and technical services, non- equity alliances, and corporate venturing investments. On the other hand Herzog (2011) categorized open innovation in two facet namely; Technology commercialization and Technology sourcing. In technology commercialization firms use external technology exploitation capability, divestment of firm units and strategic alliances. In technology sourcing, firms can use Internal R\&D, acquisitions, equity alliances, and non-equity alliances. Moreover, Lee et al. (2010) regarding to value network and collaboration categorized open innovation to three types which namely inter-firm alliance, strategic alliance, and customer-provider. In exploration (R\&D) regarding to inter-firm alliance use network, strategic alliance uses joint-venture and R\&D partnership, and in customer-provider facet, companies implement licensing, funding, and outsourcing. On the other hand, in exploitation inter-firm alliance, strategic alliance, and customer-provider use network, partnership, and outsourcing, respectively.

\section{Research Design}

A systematic literature search is used to conceptualize an open innovation effectiveness framework adapted fromBryman (2008) approach. In the first step, the research question is defined as a means to guide the purpose of the review. The second step establishes the criteria to guide the selection of studies through identifying appropriate databases for research context searches and use of relevant keywords. The third step synthesizes the literature review with the development of a conceptual framework. The research question is:

RQ: What are the activities and impact of open innovation effectiveness in innovative firms?

The bibliometric search was intended to cover studies on open innovation adoption published between 2003 and March 2014. The second step was to conduct a database search using the search term 'open innovation.' We used a number of databases (e.g. ISI Web of Science, Ebscohost, Emerald, IEEE, Sage, Springer, Proquest) and selected articles that had 'open innovation' in the title, keywords or abstract. Similarly, the timeframe was restricted to articles published from 2003 onwards, as the term 'open innovation' was originally coined in 
2003. Afterward, the articles were read and footnotes and references to other articles were followed. This led to the inclusion of working papers, dissertations, and NGO publications. Next, we searched for studies with the keywords 'external sources of innovation,' which are related to 'open innovation.'

Given the focus on external sources of innovation and open innovation activities, the authors manually reviewed abstracts for each of the 286 publications in the sample to specify whether each relates to the study and which phase(s) of the process model it discusses. When an abstract was inconclusive or unavailable, the full paper was examined. Based on the aim of this state-of-the-art review, a set of three criteria was developed in order to select a limited number of comparable studies that would enable us to answer the research question. The articles ultimately selected had to meet the following criteria:

\subsection{Definition of open innovation}

As open innovation is not a clear-cut concept, it can come in many forms (Huizingh, 2011) and the definitions used might be substantially different from ours. In our understanding, open innovation encompasses various inbound, outbound, and coupled activities, as defined by Gassmann and Enkel (2004) and Chesbrough (2003a, 2006a). Therefore we only selected studies that cover all or a considerable proportion of these activities, and do not focus on particular subjects, such as user innovation or open source. For each study, we analyzed how the term 'open innovation' was used in the article and whether it corresponds to our definition of open innovation.

\subsection{Quantitative-oriented empirical studies}

Case studies are an important method of advancing research, but large-scale studies are the only reliable option if the goal is to validate propositions and theories empirically. Therefore, 'success stories' based on single organizations had to be excluded, as these single-firm case studies cannot be generalized. Following this logic, multiple-firm case studies with only a small number of cases were also excluded (Chesbrough \& Crowther, 2006; Chiaroni, Chiesa, \& Frattini, 2010; Gassmann \& Enkel, 2004), as such studies do not provide comparable quantitative data.

\subsection{Firm focus}

Open innovation was originally introduced as a firm-level concept. van de Vrande et al. (2009) mentioned that $50 \%$ of the empirical papers in their sample took the firm as the unit of analysis. Therefore, it makes sense for us to focus on this area, which is by far the most extensively covered, in order to ensure that our studies are more easily comparable with each other. Thus, we identified 286 documents in scholarly journals, leaving 80 articles about open innovation that fulfilled the search criteria and were analyzed.

After reviewing the literature on open innovation, a list of practices, which were used by companies in prior studies, was created. Table 1 shows these practices and researcher who proposed them. In this study, open innovation survey was distributed to Malaysian SMEs that were randomly selected from SMI/SME Business Directory 2013. A total of 411 key 
informants completed the survey, which corresponds to a response rate of 23.96 per cent. Compared to other studies this result can be considered as good. In total, 11 responses had to be excluded because of missing answers or lack of influence of the key informant.

A"construct like open innovation cannot be measured directly. Therefore, the researcher has to developed a measureable indicator for open innovation adoption, which operationalized on a five-point Likert-type scales where 1- Never used, 2- Rarely used, 3- Sometimes used, 4Very Often used, 5- Always used. Researcher will be used the established scale of Laursen and Salter (2006) to measure the adoption of open innovation. While Laursen and Salter (2006) used a concept of breadth and depth for measuring openness, but in 5-point Likert scale like as Drechsler and Natter (2008), Schroll and Mild (2011), and Inauen and Schenker-Wicki $(2011,2012)$ and the questionnaire had 36 questions. In order to assess the reliability, the internal consistency of each domain was calculated using Cronbach's $\alpha$. Instruments with Cronbach's $\alpha$ value of 0.70 or greater are considered to have satisfactory internal consistency. Cronbach's $\alpha$ value for the total score"was 0.923 .

Table 1. List of open innovation practices and definitions

\begin{tabular}{|l|l|}
\hline Practices & \multicolumn{1}{|c|}{ Definition } \\
\hline 1- Purchasing & $\begin{array}{l}\text { Purchasing licenses, patents or know-how from other firms (Acha, 2008; } \\
\text { Dahlander \& Gann, 2010; Drechsler \& Natter, 2008; Eirma, 2004; Fu \& } \\
\text { Xiong, 2011; Gassmann \& Enkel, 2004; Laursen \& Salter, 2006; Schroll } \\
\text { \& Mild, 2011). }\end{array}$ \\
\hline 2- Selling & $\begin{array}{l}\text { Selling internal technologies (intellectual property; patents, copyrights } \\
\text { or trademarks) to the market to better profit from them (Chesbrough, } \\
\text { 2003b, 2007; Fey \& Birkinshaw, 2005; Gassmann \& Enkel, 2004). }\end{array}$ \\
\hline $\begin{array}{l}\text { 3- Acquisition of } \\
\text { machinery }\end{array}$ & $\begin{array}{l}\text { Acquisition of new or significantly improved machinery, equipment and } \\
\text { software (Filippetti, 2011). }\end{array}$ \\
\hline 4- Licensing-in & $\begin{array}{l}\text { Obtaining a right to exploit technologies (IP; patents, copyrights or } \\
\text { trademarks) by paying royalties to external partners (Acha, 2008; } \\
\text { Dahlander \& Gann, 2010; Drechsler \& Natter, 2008; Eirma, 2004; Fey } \\
\text { \& Birkinshaw, 2005; Gassmann \& Enkel, 2004; Laursen \& Salter, 2006; } \\
\text { Schroll \& Mild, 2011; van der Meer, 2007). }\end{array}$ \\
\hline 5- Licensing-Out & $\begin{array}{l}\text { Outward licensing the internal technologies or intellectual property (IP) } \\
\text { to other firms to generates revenues in form of licensing payments, } \\
\text { instead of direct commercialization (Chesbrough, 2003b; Dahlander \& } \\
\text { Gann, 2010; Eirma, 2004; Gassmann \& Enkel, 2004; U. Lichtenthaler \& } \\
\text { Ernst, 2007; van de Vrande et al., 2009; van der Meer, 2007). }\end{array}$ \\
\hline 6- Grant Back & $\begin{array}{l}\text { An agreement for the assignment of intellectual property that obligates a } \\
\text { licensee to license any improvements made to a licensed technology } \\
\text { back to the original technology licensor. }\end{array}$ \\
\hline 7- Open Source & $\begin{array}{l}\text { Revealing internal technologies without immediate financial rewards for } \\
\text { indirect benefits to the company (Dahlander \& Gann, 2010; Schroll \& } \\
\text { Mild, 2011; West, 2007). }\end{array}$ \\
\hline Providing money from third party investors such as banks or other \\
\hline
\end{tabular}




\begin{tabular}{|c|c|}
\hline Capital & $\begin{array}{l}\text { financial institutions (Chesbrough, 2003a, 2006a; Eirma, 2004; van der } \\
\text { Meer, 2007). }\end{array}$ \\
\hline $\begin{array}{l}\text { 9- Corporate } \\
\text { Venture Capital }\end{array}$ & Investing in an external start-up that it does not part of your company. \\
\hline 10- Divesting & Divesting or selling of firm units (U. Lichtenthaler, 2008). \\
\hline $\begin{array}{l}\text { 11- Merger \& } \\
\text { Acquisition }\end{array}$ & $\begin{array}{l}\text { Buying or combining of different companies and similar entities (Herzog } \\
\text { \& Leker, 2010). }\end{array}$ \\
\hline 12- Spin-Off & $\begin{array}{l}\text { Starting up new firms drawing on internal knowledge and also with all } \\
\text { (or partially) the support from the parent company or organization that } \\
\text { may include finance, human capital, legal advice, administrative } \\
\text { services, etc. (Chesbrough, 2003b; Eirma, 2004; Schroll \& Mild, 2011; } \\
\text { van de Vrande et al., 2009; van der Meer, 2007). }\end{array}$ \\
\hline 13- Spin-Out & $\begin{array}{l}\text { Supporting that employees work with own ideas out of your company } \\
\text { (Chesbrough, 2003b; van der Meer, 2007). }\end{array}$ \\
\hline $\begin{array}{l}\text { 14- Customer } \\
\text { Involvement }\end{array}$ & $\begin{array}{l}\text { Involving customers in innovation processes (Gassmann \& Enkel, 2004; } \\
\text { Schroll \& Mild, 2011; van de Vrande et al., 2009). }\end{array}$ \\
\hline $\begin{array}{l}\text { 15- Lead User } \\
\text { Involvement }\end{array}$ & $\begin{array}{l}\text { Engaging directly with lead users and early adopters (Laursen \& Salter, } \\
\text { 2006; Riggs \& Von Hippel, 1994; E. Von Hippel, 1988). }\end{array}$ \\
\hline $\begin{array}{l}\text { 16- Employee } \\
\text { Involvement }\end{array}$ & $\begin{array}{l}\text { Using knowledge of employees are not employed at the internal R\&D } \\
\text { department (Chesbrough \& Crowther, 2006; Van de Ven, 1986; van de } \\
\text { Vrande et al., 2009; Van Dijk \& Van Den Ende, 2002). }\end{array}$ \\
\hline $\begin{array}{l}\text { 17- Out Sourcing } \\
\text { (Contract R\&D) }\end{array}$ & $\begin{array}{l}\text { Contracting out R\&D projects or an internal business process to a } \\
\text { third-party organization (Abulrub \& Lee, 2012; Fey \& Birkinshaw, } \\
\text { 2005; van de Vrande et al., 2009). }\end{array}$ \\
\hline 18- Consulting & $\begin{array}{l}\text { Collaborating with external consultants to acquire new knowledge or } \\
\text { consulting external experts to solve the problems of innovation and } \\
\text { information sharing (Chesbrough, 2003a; Gassmann \& Enkel, 2004; } \\
\text { Schroll \& Mild, 2011; van der Meer, 2007). }\end{array}$ \\
\hline 19- Join research & $\begin{array}{l}\text { Joint research with universities or public and private R\&D institutes or } \\
\text { etc. (Abulrub \& Lee, 2012; Chesbrough, 2003b; Contractor, Kim, \& } \\
\text { Beldona, 2003; Eirma, 2004; Fey \& Birkinshaw, 2005). }\end{array}$ \\
\hline $\begin{array}{l}\text { 20- Joint } \\
\text { development }\end{array}$ & $\begin{array}{l}\text { Joint development with universities or public and private R\&D institutes } \\
\text { or etc. (Abulrub \& Lee, 2012; Chesbrough, 2003b; Contractor et al., } \\
\text { 2003; Eirma, 2004; Fey \& Birkinshaw, 2005). }\end{array}$ \\
\hline $\begin{array}{l}\text { 21- Crowd } \\
\text { Sourcing }\end{array}$ & $\begin{array}{l}\text { Making an open online call for a creative idea, problem-solving, } \\
\text { evaluation or any other type of business issues, and to let anyone (in the } \\
\text { crowd) submit solutions (Howe, 2008; Kleemann, Voß, \& Rieder, 2008; } \\
\text { Lakhani, 2008; F. Piller, 2009; Ribiere \& Tuggle, 2010; Yang, Adamic, } \\
\text { \& Ackerman, 2008). }\end{array}$ \\
\hline $\begin{array}{l}\text { 22- Crowd } \\
\text { funding }\end{array}$ & $\begin{array}{l}\text { Using external finance from a large group of people that provides a very } \\
\text { small amount (Belleflamme, Lambert, \& Schwienbacher, 2011; } \\
\text { Ordanini, Miceli, Pizzetti, \& Parasuraman, 2011). }\end{array}$ \\
\hline 23- Online Portal & ing Online portal to inter ideas to allow others outside the company to \\
\hline
\end{tabular}




\begin{tabular}{|c|c|}
\hline for Inter Ideas & submit their ideas and innovations [52]. \\
\hline $\begin{array}{l}\text { 24- Technology } \\
\text { Sourcing }\end{array}$ & $\begin{array}{l}\text { Outsourcing a task to a large group of people outside the organization to } \\
\text { introduce new technology solutions (Sloane, 2011). }\end{array}$ \\
\hline $\begin{array}{l}\text { 25- Technology } \\
\text { Scouting }\end{array}$ & $\begin{array}{l}\text { Assigning part of firm employees to achieve innovations with } \\
\text { differentiation characteristics or identifying emerging technologies (Ili, } \\
\text { Albers, \& Miller, 2010; Rohrbeck, 2010; Wolff, 1992). }\end{array}$ \\
\hline $\begin{array}{l}\text { 26- Mass } \\
\text { Customization }\end{array}$ & $\begin{array}{l}\text { Offering to the costumers to personalise (customise) a product online (F. } \\
\text { Piller, 2009; F. T. Piller, 2004). }\end{array}$ \\
\hline $\begin{array}{l}\text { 27- Learning } \\
\text { Journeys }\end{array}$ & $\begin{array}{l}\text { Using learning journeys to pick up important information (Ili et al., } \\
\text { 2010). }\end{array}$ \\
\hline $\begin{array}{l}\text { 28- External } \\
\text { participations }\end{array}$ & $\begin{array}{l}\text { External participation refers to participating in fairs, exhibitions, } \\
\text { research consortium, meeting or conferences, which this kind of } \\
\text { activities has a mutual propose for companies that can both share and } \\
\text { capture knowledge (Cosh \& Zhang, 2011; Gronum \& Verreynne, 2011; } \\
\text { Howells, Ramlogan, \& Cheng, 2012; Ili et al., 2010). }\end{array}$ \\
\hline $\begin{array}{l}\text { 29- Personnel } \\
\text { exchange }\end{array}$ & $\begin{array}{l}\text { Exchanging personnel with other firms to capture information and } \\
\text { knowledge (Ili et al., 2010) }\end{array}$ \\
\hline $\begin{array}{l}\text { 30- Sharing } \\
\text { facilities }\end{array}$ & $\begin{array}{l}\text { Sharing facilities with other organizations, inventors, researchers, etc. } \\
\text { (Chesbrough \& Brunswicker, 2013). }\end{array}$ \\
\hline $\begin{array}{l}\text { 31- Revers } \\
\text { engineering }\end{array}$ & Capturing new information or knowledge through reverse engineering. \\
\hline $\begin{array}{l}\text { 32- Contract } \\
\text { research }\end{array}$ & Providing contract research to other external sources \\
\hline $\begin{array}{l}\text { 33- Joint } \\
\text { Purchasing }\end{array}$ & $\begin{array}{l}\text { It is cooperation between two or more organizations in a purchasing } \\
\text { group in one or more steps of the purchasing process by sharing and/or } \\
\text { bundling their purchasing volumes, information, and/or resources } \\
\text { (Hendrick, 1996; Lambe, Spekman, \& Hunt, 2002; Schotanus \& Telgen, } \\
\text { 2007). }\end{array}$ \\
\hline $\begin{array}{l}\text { 34- Joint } \\
\text { procurement }\end{array}$ & $\begin{array}{l}\text { Joint procurement means combining the procurement actions of two or } \\
\text { more contracting authorities and there should be only one tender } \\
\text { published on behalf of all participating authorities. }\end{array}$ \\
\hline $\begin{array}{l}\text { 35- Joint } \\
\text { marketing } \\
\text { (Co-Branding) }\end{array}$ & $\begin{array}{l}\text { Refers to any situation where a product is manufactured by one company } \\
\text { and distributed by another company and both parties invest in } \\
\text { commercialization (Grossman, 1997; Kumar, 2005; Leuthesser, Kohli, \& } \\
\text { Suri, 2003). }\end{array}$ \\
\hline $\begin{array}{l}\text { 36- Joint } \\
\text { manufacturing }\end{array}$ & Joint production of products or goods or services. \\
\hline
\end{tabular}

\section{Analysis of research results}

Descriptive-correlation research method is used for this study. For categorizing open innovation practices Exploratory Factor Analysis (EFA) was used. To perform this statistical method SPSS 19 was used. EFA is a statistical tool used to reduce a large amount of data to a small number of factors and in this study is open innovation approach, to detect the presence 
of meaningful patterns among the original variables, and to extract the main service factors indicating associations between sets of many interrelated variables. In the first step Bartlett's test of sphericity and the Kaiser-Mayer-Olkin (KMO) test were performed. Bartlett's test of Sphericity determines whether the correlation matrix is an identity matrix. If an identity matrix exists, then, factor analysis will be meaningless. The KMO test measures the adequacy of a sample in terms of the distribution of values, for the execution of factor analysis. An acceptable value for the KMO test is greater than 0.5. Coefficients used to interpret common factors are in bold. Extraction method: Principal Component Analysis (PCA). Rotation method: varimax with Kaiser normalization. According to the result of the KMO measurement value of a sampling adequacy of 0.874 , the data were deemed to be appropriate for the analysis. Bartlett's test of sphericity was high at 0.000 that shows a probability value lowers than 0.001 . This result shown, that correlations do exist between some of the response categories. Both the KMO and the Bartlett's test of sphericity measure of sampling adequacy verified the use of factor analysis for this research.

Table 2. KMO and Bartlett's Test

\begin{tabular}{|l|r|r|}
\hline \multicolumn{2}{|l|}{ Kaiser-Meyer-Olkin Measure of Sampling Adequacy. } & .874 \\
\hline \multirow{3}{*}{ Bartlett's Test of Sphericity } & Approx. Chi-Square & 10147.238 \\
& df & 630 \\
\cline { 2 - 3 } & Sig. & .000 \\
\hline
\end{tabular}

PCA extraction method run, as it is indicated in Table 3 (after varimax with Kaiser normalization rotation) there are only three factors with eigenvalue more than 1 . According to rotation sum of squared loading, $52.12 \%$ of variances totally explain by these three factors. Factor. loadings are the correlations. of the variables. with a factor. The realistic. meaning of. a factor. can be. synthesized by combining. those variables, which have a relatively. high factor. loading when performing a principal. component factor. analysis with. varimax rotation. Variables are. loaded maximally. to only one. factor and minimally. to the remaining. factors. This analysis provides a clearer picture of what these factors represent. The. resulting. key. safety. factor. dimensions. are. identified. in Table 4.

Based on the results of factor analysis 36 practices identified in this study categorized to three categories as Gassmann and Enkel (2004) identified three-core processes of open innovation. Factor 1, which we refer it as Outside-in open innovation includes 20 practices, which all the practices in this factor are associated with the firms monitor their environment with the object of sourcing technology and knowledge in addition to the in-house R \& D (Gronum \& Verreynne, 2011). The outside-in open innovation points to necessity of external innovation sources in order to generate internal research and development activities.

Factor 2 that includes eight practices named as inside-out process, commercialisation of technologies, ideas and innovations through distribution channels externally means inside-out open innovation. Such process is related to obtaining profits via providing ideas to market, multiplying technology through transfer of ideas to outside context and also selling out intellectual property (Enkel, Gassmann, \& Chesbrough, 2009; Fu \& Xiong, 2011; Gassmann 


\section{Macrothink

\& Enkel, 2004). Finally the third factor also covers eight practices that we called coupled open innovation which firms using for reaching such goals, these firms cooperate with other firms within strategic networks (Gassmann \& Enkel, 2004) by working in alliances with complementary partners. Then, firms can get increased returns through multiplying their own exploitation via selecting coupled process as their key process. 
Table 3. Total Variance Explained

\begin{tabular}{|c|c|c|c|c|c|c|}
\hline \multirow[t]{2}{*}{ Component } & \multicolumn{3}{|c|}{ Initial Eigenvalues } & \multicolumn{3}{|c|}{ Rotation Sums of Squared Loadings } \\
\hline & Total & $\begin{array}{c}\% \text { of } \\
\text { Variance }\end{array}$ & $\begin{array}{c}\text { Cumulative } \\
\%\end{array}$ & Total & $\begin{array}{c}\% \text { of } \\
\text { Variance }\end{array}$ & Cumulative $\%$ \\
\hline 1 & 11.088 & 30.800 & 30.800 & 9.394 & 26.094 & 26.094 \\
\hline 2 & 3.162 & 8.782 & 39.582 & 4.398 & 12.216 & 38.311 \\
\hline 3 & 2.588 & 7.190 & 52.127 & 3.046 & 8.461 & 52.127 \\
\hline 4 & 1.928 & 5.356 & 54.226 & & & \\
\hline 5 & 1.594 & 4.428 & 56.555 & & & \\
\hline 6 & 1.317 & 3.659 & 60.214 & & & \\
\hline 7 & 1.196 & 3.322 & 63.536 & & & \\
\hline 8 & 1.126 & 3.127 & 66.663 & & & \\
\hline 9 & 1.036 & 2.879 & 69.542 & & & \\
\hline 10 & .926 & 2.571 & 72.113 & & & \\
\hline 11 & .857 & 2.380 & 74.493 & & & \\
\hline 12 & .756 & 2.101 & 76.594 & & & \\
\hline 13 & .731 & 2.030 & 78.625 & & & \\
\hline 14 & .694 & 1.927 & 80.552 & & & \\
\hline 15 & .633 & 1.758 & 82.309 & & & \\
\hline 16 & .624 & 1.733 & 84.043 & & & \\
\hline 17 & .587 & 1.630 & 85.672 & & & \\
\hline 18 & .534 & 1.482 & 87.155 & & & \\
\hline 19 & .513 & 1.425 & 88.579 & & & \\
\hline 20 & .466 & 1.295 & 89.875 & & & \\
\hline 21 & .422 & 1.172 & 91.046 & & & \\
\hline 22 & .404 & 1.123 & 92.169 & & & \\
\hline 23 & .387 & 1.076 & 93.245 & & & \\
\hline 24 & .355 & .987 & 94.232 & & & \\
\hline 25 & .341 & .947 & 95.179 & & & \\
\hline 26 & .314 & .873 & 96.052 & & & \\
\hline 27 & .302 & .838 & 96.890 & & & \\
\hline 28 & .283 & .786 & 97.676 & & & \\
\hline 29 & .195 & .542 & 98.218 & & & \\
\hline 30 & .152 & .424 & 98.641 & & & \\
\hline 31 & .141 & .390 & 99.032 & & & \\
\hline 32 & .126 & .349 & 99.381 & & & \\
\hline 33 & .082 & .227 & 99.608 & & & \\
\hline 34 & .063 & .176 & 99.784 & & & \\
\hline 35 & .048 & .132 & 99.916 & & & \\
\hline 36 & .030 & .084 & 100.000 & & & \\
\hline
\end{tabular}


Table 4. Rotated Component Matrix

\begin{tabular}{|c|c|c|c|}
\hline \multirow[t]{2}{*}{ Items (Practices) } & \multicolumn{3}{|c|}{ Component } \\
\hline & 1 & 2 & 3 \\
\hline Purchasing & .553 & -.064 & .406 \\
\hline Acquisition of Machinery & .735 & .151 & -.089 \\
\hline Licensing-In & .695 & -.001 & -.040 \\
\hline Venture Capital & .597 & .291 & .066 \\
\hline Customer Involvement & .650 & .042 & -.103 \\
\hline Lead User Involvement & .517 & .373 & -.103 \\
\hline Employee Involvement & 600 & .142 & -.014 \\
\hline Consulting & .754 & .064 & -.010 \\
\hline Crowd Sourcing & .809 & .141 & .037 \\
\hline Crowd Founding & .779 & .214 & -.037 \\
\hline Out Sourcing (Contract R\&D) & .565 & .298 & -.025 \\
\hline Technology Sourcing & .776 & .158 & -.017 \\
\hline Technology Scouting & .761 & .119 & -.038 \\
\hline Mass Customization & .601 & .109 & -.040 \\
\hline Learning Journeys & .525 & .142 & .314 \\
\hline Online Portal for Inter Ideas & .552 & .201 & -.179 \\
\hline Merger \& Acquisition & .679 & .311 & .094 \\
\hline Sharing Facilities & .685 & .392 & -.148 \\
\hline Revers Engineering & .680 & .061 & .428 \\
\hline Contract Research & .464 & .275 & -.127 \\
\hline Selling & .040 & .786 & .241 \\
\hline Divesting & .089 & .673 & -.073 \\
\hline Licensing-Out & .144 & .804 & .163 \\
\hline Spin-Off & .097 & .569 & -.142 \\
\hline Spin-Out & .383 & .477 & -.159 \\
\hline Grant Back License & .267 & .684 & -.002 \\
\hline Open Source & .147 & .542 & .327 \\
\hline Corporate Venture Capital & .150 & .574 & -.114 \\
\hline Joint Development & .170 & .224 & .781 \\
\hline Joint Research & .167 & .216 & .813 \\
\hline Joint Purchasing & .163 & .057 & .791 \\
\hline Joint Procurement & .147 & .053 & .791 \\
\hline Joint Marketing (Co-Branding) & .083 & .089 & .440 \\
\hline Joint Manufacturing & .388 & .165 & .491 \\
\hline External Participations & .293 & .205 & .557 \\
\hline Personnel Exchange & .073 & .267 & .661 \\
\hline
\end{tabular}

Extraction Method: Principal Component Analysis

Rotation Method: Varimax with Kaiser Normalization

To rank these factors, which will be called Open Innovation process, descriptive statistics test 
has been run. Table 5 demonstrates descriptive statistics of open innovation process ranking in Malaysian SMEs. With a mean of 2.89 (5-point Likert scale), coupled activities are considered as the most frequent employed innovation acts in the Malaysian SMEs as compared to the Outside-in activities with a mean of 2.32 and inside-out activities obviously are utilized less with a mean equal to 1.54. In order to know which category of open innovation practices (outside-in, inside-out, coupled) are more used than others, the adoption variable's confidence intervals are estimated at 95\% level. On the other side, interval's lower bound for coupled activities is equal to 2.81, whilst the interval's upper bound for the outside-in and inside-out respectively lies at 2.38 and 1.60. Therefore, the activities of coupled open innovation have been utilized more significantly after those outside-in activities.

Table 5. Results of ranking open innovation process

\begin{tabular}{|c|c|c|c|c|c|}
\hline Approaches & Mean Rank & Rank & Std. Deviation & $95 \%$ CI Low & $95 \%$ CI High \\
\hline $\begin{array}{c}\text { Coupled } \\
\text { activities }\end{array}$ & 2.8981 & 1 & 0.8873 & 2.8109 & 2.9853 \\
\hline $\begin{array}{c}\text { Outside-in } \\
\text { activities }\end{array}$ & 2.321 & 2 & 0.65653 & 2.2565 & 2.3856 \\
\hline $\begin{array}{c}\text { Inside-out } \\
\text { activities }\end{array}$ & 1.5481 & 3 & 0.57356 & 1.4917 & 1.6045 \\
\hline
\end{tabular}

\section{Conclusion}

Prior studies suggested various kinds of open innovation practices and different ways of categorization of them and most of studies only used some of the practices to measured open innovation, but the measurements were very generic as some practices are broadly defined, and the list of open innovation activities not included new activities and completed list of practices. In addition, most of prior researches have been conducted in developed countries. Hence, it is important to identify a new list of practices of open innovation and study on similar practices in developing countries to help their firms understand these practices and open innovation as well. Furthermore, classifying these practices to understand approaches among several practices of open innovation will be great helpful tool for researchers and managers.

In this study, we identified 36 practices using by different enterprises to do open innovation. Then, we have tested these practices in Malaysian SMEs and categorized them into three core processes as Gassmann and Enkle (2004) mentioned by using EFA. These three processes of open innovation explain $52.12 \%$ of shared variance. Moreover, all individual practices were best associated with their conceptual original factors. To rank these processes and to distinguish which process is used, more than other in Malaysian SMEs descriptive statistics tests were used. Therefore, the results of descriptive statistics revealed that the practices of coupled open innovation have been utilized more significantly and after those outside-in and inside-out practices, respectively. 


\section{References}

Abulrub, A.-H. G., \& Lee, J. (2012). Open innovation management: challenges and prospects. Procedia-Social and Behavioral Sciences, 41, 130-138.

Acha, V. (2008, 2008). OPEN BY DESIGN: THE ROLE OF DESIGN IN OPEN INNOVATION, United Kingdom.

Arora, A., Fosfuri, A., \& Gambardella, A. (2001). Markets for technology and their implications for corporate strategy. Industrial and Corporate Change, 10(2), 419-451.

Belleflamme, P., Lambert, T., \& Schwienbacher, A. (2011, 2011). Crowdfunding: Tapping the right crowd.

Bianchi, M., Cavaliere, A., Chiaroni, D., Frattini, F., \& Chiesa, V. (2011). Organisational modes for Open Innovation in the bio-pharmaceutical industry: An exploratory analysis. Technovation, 31(1), 22-33. http://dx.doi.org/10.1016/j.technovation.2010.03.002

Bryman, A. (2008). Social research methods. New York, NY: Oxford university press.

Chandler, A. D. (1977). The visible hand: The managerial revolution in American business. Cambridge, MA.: Belknap Press.

Chandler, A. D. (1990). Scale and Scope: The Dynamics of Industrial Capitalism. Cambridge, MA.: Harvard University Press.

Chesbrough, H. (2003a). The era of open innovation. Sloan Management Review, 44(3), 35-41.

Chesbrough, H. (2003b). Open Innovation: The New Imperative for Creating and Profiting from Technology. Boston, MA: Harvard Business School Publishing.

Chesbrough, H. (2006a). The era of open innovation. Managing innovation and change, 127(3), 34-41.

Chesbrough, H. (2006b). Open business models. Boston, MA: Harvard Business Press.

Chesbrough, H. (2007). Why companies should have open business models. MIT Sloan Management Review, 48(2), 22-28.

Chesbrough, H., \& Brunswicker, S. (2013). Managing open innovation in large firms: Fraunhofer Verlag.

Chesbrough, H., \& Crowther, A. K. (2006). Beyond high tech: early adopters of open innovation in other industries. R\&D Management, 36(3), 229-236.

Chesbrough, H., Vanhaverbeke, W., \& West, J. (2006). Open Innovation: Researching a New Paradigm: Oxford university press.

Chiaroni, D., Chiesa, V., \& Frattini, F. (2010). Unravelling the process from Closed to Open Innovation: evidence from mature, asset-intensive industries. R\&D Management, 40(3), 222-245. http://dx.doi.org/10.1111/j.1467-9310.2010.00589.x 
Contractor, F. J., Kim, C. S., \& Beldona, S. (2003). Interfirm learning in alliance and technology networks: an empirical study in the global pharmaceutical and chemical industries (pp. 493-516). Boston, MA: Elsevier Science.

Cosh, A., \& Zhang, J. J. (2011). Open Innovation Choices: What is British Enterprise Doing? : Centre for Business Research.

Dahlander, L., \& Gann, D. M. (2010). How open is innovation? Research Policy, 39(6), 699-709.

Drechsler, W., \& Natter, M. (2008, 2008). Open innovation - management trend with impact? An empirical investigation of antecedents, drivers and performance outcomes, Frankfurt.

Eirma. (2004). Technology access for open innovation (Woking Group Report: no 63). Paris: EIRMA.

Elmquist, M., Fredberg, T., \& Ollila, S. (2009). Exploring the field of open innovation. European Journal of Innovation Management, 12(3), 326-345.

Enkel, E., Gassmann, O., \& Chesbrough, H. (2009). Open R\&D and open innovation: Exploring the phenomenon. $R$ and D Management, 39(4), 311-316.

Fey, C. F., \& Birkinshaw, J. (2005). External sources of knowledge, governance mode, and R\&D performance. Journal of Management, 31(4), 597-621. doi: $10.1177 / 0149206304272346$

Filippetti, A. (2011). Innovation modes and design as a source of innovation: a firm-level analysis. European Journal of Innovation Management, 14(1), 5-26.

Fu, X., \& Xiong, H. (2011). Open innovation in China: policies and practices. Journal of Science and Technology Policy in China, 2(3), 196-218. http://dx.doi.org/10.1108/17585521111167243

Gassmann, O., \& Enkel, E. (2004, 2004). Towards a theory of open innovation: Three core process archetypes, Lisbon.

Gronum, S., \& Verreynne, M.-L. (2011, 2011). Open innovation in Australian small firms: When should we collaborate?

Grossman, R. P. (1997). Co-branding in advertising: developing effective associations. Journal of Product \& Brand Management, 6(3), 191-201.

Hendrick, T. E. (1996). Purchasing consortiums: Horizontal alliances among firms buying common goods and services: What? who? why? how? : Center for Advanced Purchasing Studies.

Herzog, P. (2011). Open and closed innovation: Springer.

Herzog, P., \& Leker, J. (2010). Open and closed innovation-different innovation cultures for different strategies. International Journal of Technology Management, 52(3), 322-343. 
Howe, J. (2008). Crowdsourcing: Why the Power of the Crowd is Driving the Future of Business. New York: Crown Publishing Group.

Howells, J., Ramlogan, R., \& Cheng, S. L. (2012). Universities in an open innovation system: A UK perspective. International Journal of Entrepreneurial Behaviour and Research, 18(4), 440-456. http://dx.doi.org/10.1108/13552551211239483

Hu, H.-Y., \& Chen, W.-Y. (2011, 2011). The key factors for open innovation: An empirical study from Taiwan CIS survey.

Huizingh, E. K. R. E. (2011). Open innovation: State of the art and future perspectives. Technovation, 31(1), 2-9. http://dx.doi.org/10.1016/j.technovation.2010.10.002

Idrissia, M. O., Amaraa, N., \& Landrya, R. (2012). SMEs' degree of openness: The case of manufacturing industries. Journal of Technology Management and Innovation, 7(1), 186-210.

Ili, S., Albers, A., \& Miller, S. (2010). Open innovation in the automotive industry. $R \& D$ Management, 40(3), 246-255.

Inauen, M., \& Schenker-Wicki, A. (2011). The impact of outside-in open innovation on innovation performance. European Journal of Innovation Management, 14(4), 496-520. doi: $10.1108 / 14601061111174934$

Inauen, M., \& Schenker-Wicki, A. (2012). Fostering radical innovations with open innovation. European Journal of Innovation Management, 15(2), 212-231. http://dx.doi.org/10.1108/14601061211220977

Kleemann, F., Voß, G. G., \& Rieder, K. (2008). Un (der) paid Innovators: The Commercial Utiliza-tion of Consumer Work through Crowdsourcing. Science, Technology \& Innovation Studies, 4(1), 5-5.

Kumar, P. (2005). The impact of cobranding on customer evaluation of brand counterextensions. Journal of Marketing, 1-18.

Lakhani, K. R. (2008). InnoCentive. com (A). Harvard Business School Case(608-170).

Lambe, C. J., Spekman, R. E., \& Hunt, S. D. (2002). Alliance competence, resources, and alliance success: conceptualization, measurement, and initial test. Journal of the Academy of Marketing Science, 30(2), 141-158.

Laursen, K., \& Salter, A. (2006). Open for innovation: the role of openness in explaining innovation performance among U.K. manufacturing firms. Strategic Management Journal, 27(2), 131-150. http://dx.doi.org/10.1002/smj.507

Lee, S., Park, G., Yoon, B., \& Park, J. (2010). Open innovation in SMEs-An intermediated network model. Research Policy, 39(2), 290-300. http://dx.doi.org/10.1016/j.respol.2009.12.009

Leuthesser, L., Kohli, C., \& Suri, R. (2003). Academic Papers $2+2=5$ ? A framework for using co-branding to leverage a brand. The Journal of Brand Management, 11(1), 35-47. 
Lichtenthaler, U. (2007). The drivers of technology licensing: An industry comparison. California Management Review, 49(4), 67-89.

Lichtenthaler, U. (2008). Open innovation in practice: An analysis of strategic approaches to technology transactions. IEEE Transactions on Engineering Management, 55(1), 148-157.

Lichtenthaler, U., \& Ernst, H. (2007). External technology commercialization in large firms: Results of a quantitative benchmarking study. $R$ and D Management, 37(5), 383-397.

Ordanini, A., Miceli, L., Pizzetti, M., \& Parasuraman, a. (2011). Crowd-funding: transforming customers into investors through innovative service platforms. Journal of Service Management, 22(4), 443-470. http://dx.doi.org/10.1108/09564231111155079

Piller, F. (2009, 2009). The future of open innovation.

Piller, F. T. (2004). Mass customization: reflections on the state of the concept. International Journal of Flexible Manufacturing Systems, 16(4), 313-334.

Ribiere, V. M., \& Tuggle, F. D. D. (2010). Fostering innovation with KM 2.0. VINE, 40(1), 90-101. doi: http://dx.doi.org/10.1108/03055721011024955

Riggs, W., \& Von Hippel, E. (1994). Incentives to innovate and the sources of innovation: The case of scientific instruments. Research Policy, 23(4), 459-469.

Rohrbeck, R. (2010). Harnessing a network of experts for competitive advantage: technology scouting in the ICT industry. R\&D Management, 40(2), 169-180.

Rosenbusch, N., Brinckmann, J., \& Bausch, A. (2011). Is innovation always beneficial? A meta-analysis of the relationship between innovation and performance in SMEs. Journal of Business Venturing, 26(4), 441-457. http://dx.doi.org/10.1016/j.jbusvent.2009.12.002

Schotanus, F., \& Telgen, J. (2007). Developing a typology of organisational forms of cooperative purchasing. Journal of Purchasing and Supply Management, 13(1), 53-68. http://dx.doi.org/10.1016/j.pursup.2007.03.002

Schroll, A., \& Mild, A. (2011). Open innovation modes and the role of internal R\&D: An empirical study on open innovation adoption in Europe. European Journal of Innovation Management, 14(4), 475-495. http://dx.doi.org/10.1108/14601061111174925

Sloane, P. (2011). The brave new world of open innovation. Strategic Direction, 27(5), 3-4. http://dx.doi.org/10.1108/02580541111125725

Suh, Y., \& Kim, M.-S. (2012). Effects of SME collaboration on R\&D in the service sector in open innovation. Innovation: Management, Policy \& Practice, 14(3), 349-362.

Toedtling, F., Grillitsch, M., \& Hoeglinger, C. (2012). Knowledge Sourcing and Innovation in Austrian ICT Companies-How Does Geography Matter? Industry and Innovation, 19(4), 327-348.

Van de Ven, A. H. (1986). Central problems in the management of innovation. Management Science, 32(5), 590-607. 
van de Vrande, V., de Jong, J. P. J., Vanhaverbeke, W., \& de Rochemont, M. (2009). Open innovation in SMEs: Trends, motives and management challenges. Technovation, 29(6-7), 423-437. http://dx.doi.org/10.1016/j.technovation.2008.10.001

Van De Vrande, V., Lemmens, C., \& Vanhaverbeke, W. (2006). Choosing governance modes for external technology sourcing. R\&D Management, 36(3), 347-363.

van der Meer, H. (2007). Open innovation - the Dutch treat: Challenges in thinking in business models. Creativity and Innovation Management, 16(2), 192-202. http://dx.doi.org/10.1111/j.1467-8691.2007.00433.x

Van Dijk, C., \& Van Den Ende, J. (2002). Suggestion systems: transferring employee creativity into practicable ideas. $R \& D$ Management, 32(5), 387-395.

Von Hippel, E. (1988). The sources of innovation. New York, NY: Oxford University Press.

Von Hippel, E. (2005). Democratizing innovation: The evolving phenomenon of user innovation. Journal für Betriebswirtschaft, 55(1), 63-78.

West, J. (2007, 2007). Value capture and value networks in open source vendor strategies.

West, J., \& Bogers, M. (2013). Leveraging external sources of innovation: a review of research on open innovation. Journal of Product Innovation Management, Forthcoming.

Wolff, M. F. (1992). Scouting for Technology. Research Technology Management, 35(2), 10-12.

Wynarczyk, P., Piperopoulos, P., \& McAdam, M. (2013). Open innovation in small and medium-sized enterprises: An overview. International Small Business Journal, 31(3), 240-255. http://dx.doi.org/10.1177/0266242612472214

Yang, J., Adamic, L. A., \& Ackerman, M. S. (2008, 2008). Crowdsourcing and knowledge sharing: strategic user behavior on taskcn.

\section{Copyright Disclaimer}

Copyright for this article is retained by the author(s), with first publication rights granted to the journal.

This is an open-access article distributed under the terms and conditions of the Creative Commons Attribution license (http://creativecommons.org/licenses/by/3.0/). 